\title{
Tempe Fermentation of Whole Grain Barley Increased Human Iron Absorption and In Vitro Iron Availability
}

\author{
Charlotte Eklund-Jonsson*,1, Ann-Sofie Sandberg ${ }^{1}$, Lena Hulthén ${ }^{2}$ and Marie Larsson Alminger ${ }^{1}$
}

\author{
${ }^{I}$ Department of Chemical and Biological Engineering, Food Science, Chalmers University of Technology, SE 41296 \\ Göteborg, Sweden; ${ }^{2}$ Department of Clinical Nutrition, Institute of Medicine, Sahlgrenska Academy at Göteborg Univer- \\ sity, PO Box 459, SE 40530 Göteborg, Sweden
}

\begin{abstract}
In this study, iron absorption from a tempe fermented whole-grain barley meal was measured, and results were compared to in vitro estimation of available iron from an equivalent meal. The tempe meal (TM) was prepared from barley fermented with Rhizopus oligosporus to reduce the phytate content $<0.5 \mu \mathrm{mol} / \mathrm{g}$. Boiled barley with preserved phytate content was used as reference meal (BBM). Iron was added to obtain a total content of $3 \mathrm{mg}$ meal in the human study, and to the in vitro meals $7 \mathrm{mg}$ of iron was added. The iron absorption from TM and BBM was $5.5 \pm 1.5 \%$ and $3.0 \pm 0.7 \%$ respectively, and in vitro iron availability was $4.9 \pm 0.2 \%$ in $\mathrm{TM}$ and $1.7 \pm 0.1 \%$ in $\mathrm{BBM}$ (absorbed fraction of total iron/meal).
\end{abstract}

To conclude, iron absorption from a barley meal was improved by reducing the phytate content via tempe fermentation, and iron absorption was predicted by direction in the in vitro experiments.

Keywords: Iron absorption, in vitro iron availability, whole grain, vegetarian, tempe, tempeh fermentation.

\section{INTRODUCTION}

Vegetarianism has often been associated with possible nutritional inadequacy, especially with regard to iron. The absorption of iron for vegetarians is lower than for nonvegetarians [1-3]. In a study by Waldmann et al. [4], as many as $40 \%$ of young female vegans were found iron deficient and Alexander et al. [5] found that vegetarians had lower serum ferritin concentrations than age-sex matched omnivores. Since iron is a necessary micronutrient, there is a need for the development of novel vegetarian products with high iron bioavailability.

Whole grain cereals are often low in iron availability due to high contents of phytate (myo-inositolhexaphospate, $\mathrm{InsP}_{6}$ ) and iron-binding polyphenols. Nevertheless, there are benefits from including cereals in the diet, like reduced risk of developing cardio vascular diseases, diabetes and obesity [6-9]. Barley is an underutilized cereal in Sweden, mainly used for animal feed [10]. Antioxidants and $\beta$-glucans are abundant in whole barley kernels [11] and compared to crops such as sorghum, millet, rice and beans, barley has a low polyphenol content [12-16]. However, the phytate content is more substantial [17] and hence, the main iron absorption inhibitor in barley. Therefore, to increase iron absorption from barley foods, degradation of the phytate content is required. Other important food factors affecting iron absorption are e.g. ascorbic acid and meat (enhancers), as well as polyphenols and calcium (inhibitors) [18, 19].

Phytate is hydrolysed via intermediate myo-inositolphosphates $\left(\mathrm{InsP}_{5}\right.$ to $\left.\mathrm{InsP}_{1}\right)$ into myo-inositol and inorganic

\footnotetext{
*Address correspondence to this author at the Department of Chemical and Biological Engineering, Food Science, Chalmers University of Technology, SE 41296 Göteborg, Sweden;

E-mail: charlotte.eklund-jonsson@chalmers.se
}

phosphate. Degradation of phytate can be achieved during food processing through the addition of exogenous phytases [20], by micro-organisms producing phytase or by endogenous cereal phytases [21]. Most cereal phytases are reported to have their $\mathrm{pH}$ optima between 4.5 and 6.0 and temperature optima between 45 and $55^{\circ} \mathrm{C}$ [22]. In the study by Greiner $e t$ al. [23] barley was found to have two phytate-degrading enzymes - P1 and P2 - with optimal conditions reported to be $45^{\circ} \mathrm{C}, \mathrm{pH} 5.0$, and $55^{\circ} \mathrm{C}, \mathrm{pH} 6.0$, respectively. The micro fungus Rhizopus oligosporus used to ferment the vegetarian food tempe [24], has a phytase with optimal capacity at $65^{\circ} \mathrm{C}$ and $\mathrm{pH} 5.0$ [25]. $R$. oligosporus has also previously been found to reduce phytate content of e.g. soybeans and oilcakes during fermentation, although not to very low levels [26-28]. However, effective enhancement of iron absorption requires almost complete degradation or removal of phytate. Hallberg et al. [29] and Brune et al. [30] found that, in order to markedly increase iron absorption, the total content of phytate-P from a meal should not exceed $10 \mathrm{mg}$. Additionally, the phytate to iron (InsP/Fe) molar ratio should be $<1$ and preferably $<0.5$ to achieve satisfactory iron absorption [31]. Nevertheless, we recently reported that it is possible to substantially reduce the phytate content and concomitantly preserving minerals in barley during tempe fermentation [32].

To assess the effect on iron bioavailability from reducing the phytate content in foods, the most reliable approach is considered conducting a human study. However, there is also a need for less time-consuming but valid models for screening of foods. Cost-effective in vitro models, capable of assessing the factors influencing iron availability, could therefore serve as important tools in predicting bioavailability [33].

To our knowledge, no studies in humans have been performed to determine the effect of low phytate tempe prod- 
ucts on iron absorption. The aim of the present investigation was to measure human iron absorption from tempe fermented whole grain barley and a reference boiled barley meal, and to compare the results with in vitro estimation of iron availability in equivalent meals using a computercontrolled gastrointestinal model.

\section{MATERIALS AND METHODS}

\section{Raw Material and Preparation of Meals}

The high B-glucan (6.3\%) and high amylose (40.7\%) variety barley, cv. Karmosé [34], was obtained from Svalöf Weibull AB, (Svalöv, Sweden). This variety was chosen since the barley tempe was simultaneously optimised to induce low glycemic response, examined in a separate study [35]. Production processes were performed at Cerealia R\&D (Järna, Sweden).

Table 1. Nutrient Content (Dry Weight) in a Portion of a TM (Tempe Meal) and a BBM (Boiled Barley Meal) of the Human and the in vitro Studies

\begin{tabular}{|c|c|c|c|c|c|c|}
\hline & \multicolumn{2}{|c|}{$\begin{array}{l}\text { Human study } \\
\qquad(n=8)\end{array}$} & \multicolumn{2}{|c|}{$\begin{array}{l}\text { In vitro study } \\
\quad(n=4)\end{array}$} & \\
\hline & & $\mathbf{T M}$ & BBM & TM & BBM & \\
\hline \multirow{2}{*}{$\begin{array}{c}\text { Meal } \\
\text { size }\end{array}$} & w.w. & 115 & 115 & 57 & 57 & $\mathrm{~g}$ \\
\hline & d.m. & 56 & 56 & 28 & 28 & $\mathrm{~g}$ \\
\hline \multicolumn{2}{|c|}{ Protein } & 2.4 & 3.2 & 1.2 & 1.6 & $\mathrm{~g}$ \\
\hline \multicolumn{2}{|c|}{ Fat } & 0.9 & 1.0 & 0.45 & 0.5 & $\mathrm{~g}$ \\
\hline \multicolumn{2}{|c|}{ Carbohydrates } & 14.8 & 17.2 & 7.4 & 8.6 & $\mathrm{~g}$ \\
\hline \multicolumn{2}{|c|}{ Dietary fibre } & 3.0 & 4.3 & 1.5 & 2.2 & $\mathrm{~g}$ \\
\hline \multicolumn{2}{|c|}{ Starch } & 12.0 & 17.7 & 6 & 8.9 & $\mathrm{~g}$ \\
\hline \multicolumn{2}{|c|}{ Water } & 64.4 & 70.6 & 32.2 & 35.3 & $\mathrm{~g}$ \\
\hline \multicolumn{2}{|c|}{ Iron (in kernels) } & 1.9 & 1.1 & 0.95 & 0.55 & $\mathrm{mg}$ \\
\hline \multirow{2}{*}{\multicolumn{2}{|c|}{ Iron (total) }} & 3.0 & 3.0 & 7.8 & 7.5 & $\mathrm{mg}$ \\
\hline & & 54 & 54 & 139 & 134 & $\mu \mathrm{mol}$ \\
\hline \multicolumn{2}{|c|}{ Phytate-P } & 6.5 & 72.3 & 3.3 & 36.2 & $\mathrm{mg}$ \\
\hline \multicolumn{2}{|c|}{$\mathrm{InsP}_{3-6}$} & 41 & 452 & 20 & 226 & $\mu \mathrm{mol}$ \\
\hline \multicolumn{2}{|c|}{$\begin{array}{l}\text { Molar ratio } \\
(\mathrm{Ins} \mathrm{P} / \mathrm{Fe})\end{array}$} & 0.8 & 8.4 & 0.4 & 1.7 & \\
\hline \multirow{2}{*}{\multicolumn{2}{|c|}{ Energy }} & 328 & 384 & 164 & 192 & $\mathrm{~kJ}$ \\
\hline & & 78 & 92 & 39 & 46 & kcal \\
\hline
\end{tabular}

To produce the tempe meal (TM), fermentations were performed according to Eklund-Jonsson et al. [30]. Briefly, barley kernels were pearled for $5 \mathrm{~min}$ in a laboratory scale grinder (Strechel und Schrader, Germany), and the pearling residue was collected. The husk was removed from the pearling residue and discarded. Pearled kernels were soaked in lactic acid $\left(0.3 \%\right.$ lactic acid; $6+4 \mathrm{~h}$ of soaking at $\left.48^{\circ} \mathrm{C}\right)$, boiled (10 $\mathrm{min}$ ) and drained before the pearling residue was returned. The fungal strain, Rhizopus oligosporus ATCC 64063, was produced according to Feng et al. [36]. The drained kernels were mixed with the pearling residue (kernel/residue mixture; $\mathrm{pH} 4.5$, water content $54 \%$ ), inoculated with $R$. oligosporus and allowed to ferment for $27 \mathrm{~h}$ at $32^{\circ} \mathrm{C}$. Tempe cakes were stored at minus $20^{\circ} \mathrm{C}$ until the day of serving. The boiled barley meal (BBM) was produced by pearling kernels for $1 \mathrm{~min}$ to remove husk, and simmering kernels in water (70 min) with $\mathrm{NaCl}$ (human study, $0.75 \mathrm{~g}$; in vitro study, $0.38 \mathrm{~g}$ per portion). The nutrient contents per portion of the TM and BBM are shown in Table $\mathbf{1}$.

\section{Human Study - Experimental Design and Subjects}

Iron absorption from the test meals was measured using two different radio iron tracers ${ }^{55} \mathrm{Fe}(\mathrm{BBM})$ and ${ }^{59} \mathrm{Fe}(\mathrm{TM})$ and each subject served as its own control. The meals were all served in a fasting state in an ABBA order, where A was the TM and $\mathrm{B}$ was the BBM. The test meals were given on four consecutive days and no food or drink was allowed for $3 \mathrm{~h}$ after the meals. Two weeks after the last serving, the total retention of ${ }^{59} \mathrm{Fe}$ was measured by whole-body counting and blood samples were taken to determine the content of ${ }^{55} \mathrm{Fe}$ and ${ }^{59} \mathrm{Fe}$ in blood. The principal design of the human study has been described in detail by Hallberg [37].

The endogenous iron content of the meals was $1.9 \mathrm{mg}$ $(\mathrm{TM})$ and $1.1 \mathrm{mg}(\mathrm{BBM})$. Iron was added $\left(\right.$ as $\left.\mathrm{FeSO}_{4} * 7 \mathrm{H}_{2} \mathrm{O}\right)$ up to $3 \mathrm{mg}$ per portion, in order to reach equal iron content in the meals, and to increase the accuracy in iron absorption measurement. This resulted in molar ratios $(\mathrm{InsP} / \mathrm{Fe})$ of 0.8 (TM) and 8.4 (BBM). The size of the test meals were $\sim 115 \mathrm{~g}$ (w.w.) and according to the energy content, meals were suitable as a snack or part of a bigger meal. The TM and BBM had slightly different nutrient compositions, with higher macronutrient levels in BBM and higher endogenous iron content in TM (Table 1). Water $(200 \mathrm{ml})$ was served with each meal and before serving the TM, $0.75 \mathrm{~g} \mathrm{NaCl}$ was added per portion ( $115 \mathrm{~g}$ w.w.).

Table 2. Age and Weight Distribution, and Haematological Measurements Among Subjects $(n=8)$ of the Human Study

\begin{tabular}{|l|c|c|}
\hline & Mean \pm SEM & Range \\
\hline \hline Age & $33 \pm 4$ & $21-53$ \\
\hline Weight & $73 \pm 5$ & $60-106$ \\
\hline Haemoglobin $(\mathrm{g} / \mathrm{l})$ & $139 \pm 5$ & $127-170$ \\
\hline Serum ferritin $(\mu \mathrm{g} / \mathrm{l})$ & $19 \pm 3$ & $6-29$ \\
\hline $\begin{array}{l}\text { Total Iron-Binding Capacity } \\
\text { TIBC, }(\mu \mathrm{mol} / \mathrm{l})\end{array}$ & $80 \pm 5$ & $57-100$ \\
\hline Blood sedimentation $(\mathrm{mm})$ & $7 \pm 3$ & $1-11$ \\
\hline Transferrin saturation $(\%)$ & $22 \pm 3$ & $10-31$ \\
\hline
\end{tabular}

Ten subjects were recruited by advertising on the campus of Göteborg University. The project was approved by the Ethics Research Committee of the Göteborg University and by the Radioisotope Committee at the Sahlgrenska University Hospital, Göteborg. The volunteers were given oral and written information about the aims and procedures prior to the study. The subjects height and weight were measured and blood samples were taken to establish; haemoglobin (g/l), serum ferritin $(\mu \mathrm{g} / \mathrm{l})$, transferrin saturation $(\%)$, blood sedi- 
mentation $(\mathrm{mm})$ and total iron-binding capacity (TIBC, $\mu \mathrm{mol} / \mathrm{l}$ ) (Table 2). Blood samples were analysed at the Central Laboratory Sahlgrenska University Hospital, Göteborg. At the time of recruitment, non of those recruited were consuming nutrient supplements, they were all non-pregnant and without known gastrointestinal disorders. However, during the study, two subjects were excluded due to infection on the basis of high blood sedimentation values $(>15 \mathrm{~mm})$. The eight accepted subjects, two men and six women were aged 21-53, and thereof five were regular blood donors.

\section{In Vitro Study Method}

A computerised dynamic gastrointestinal model - TIM (TNO gastroIntestinal Model) described in detail by Minekus et al. [38], was used for the in vitro experiments (Fig. 1). The model has previously been used for simulated digestion of cereal products to estimate iron dialyzability [39-41]. The model simulates gastric emptying and small intestinal passage of foods in the human intestinal tract with good accuracy and reproducibility [38, 42]. Physiological amounts of digestive juices are secreted [38] into the four compartments of the model - stomach, duodenum, jejunum and ileum. The composition of the different digestive juices and the experimental conditions are according to Haraldsson et al. [41].

During the experiment, the intestinal fluids were dialyzed through the semi-permeable hollow fibre filters (Hospal hemodialyzer HG-400 (cut-off 3-5 kD), Gambro, Renal Products, Lund, Sweden), allowing for dissolved nutrient and small complexes to diffuse across the membrane. The dialysed fluids were collected in the jejunal and ileal containers where samples were taken for determination of iron. Each experiment was repeated four times using a protocol suitable for semi-solid foods.

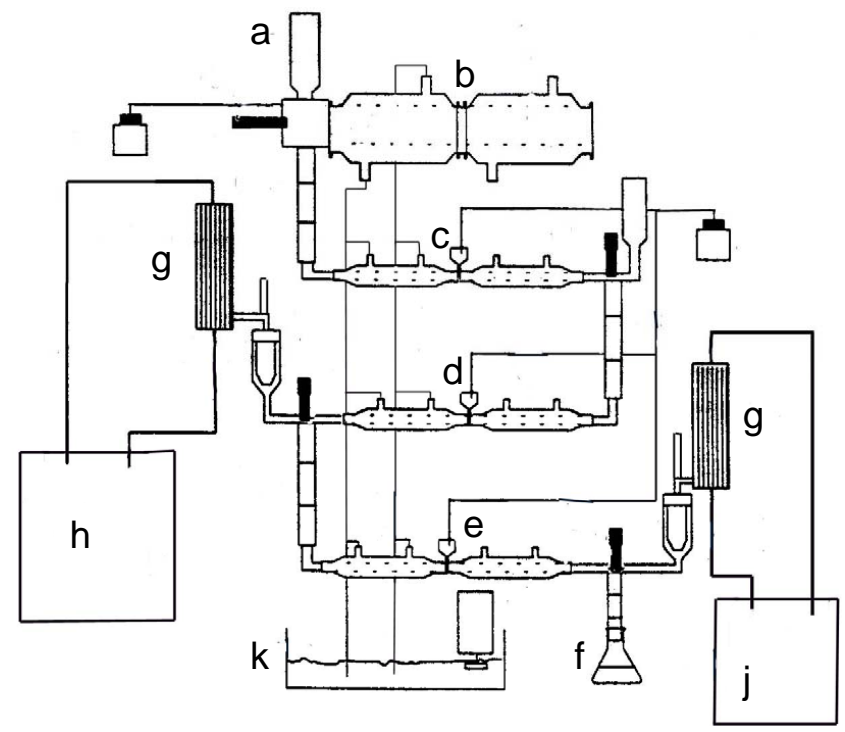

Fig. (1). Schematic picture of the TNO gastrointestinal in vitro model (TIM).

${ }^{\mathrm{a}}$ Inlet, ${ }^{\mathrm{b}}$ Stomach, ${ }^{\mathrm{c}, \mathrm{de}}$ Small intestine - duodenum, jejunum and ileum, ${ }^{\mathrm{f}}$ Ileo-cecal valve (outlet), ${ }^{\mathrm{g}}$ Semi-permeable hollow fibre filters (dialysis filters), ${ }^{\mathrm{h}, \mathrm{j}}$ Jejunal and ileal containers, ${ }^{\mathrm{k}}$ Water bath.

Compared to the human study meals, the in vitro meals were halved due to model limitations. The meals included 55 g (w.w.) and were homogenised for 30 or $60 \mathrm{~s}$ (TM and
$\mathrm{BBM}$, respectively), using a household mixer. The homogenisation method was designed after authentic chewing and the average particle size was approximately $1 \times 1 \times 2 \mathrm{~mm}$. Due to large dilution of intestinal fluids occurring in the TIM experiments, the amount of added iron was increased to enable accurate determination. To the meals, $7 \mathrm{mg}$ of iron $\left(1250 \mu \mathrm{l}, 0.1 \mathrm{M} \mathrm{FeSO}_{4}\right.$ in $\left.0.1 \mathrm{M} \mathrm{HCl}\right)$ was added up to a total of $7.8 \mathrm{mg}$ in a TM and $7.5 \mathrm{mg}$ in a BBM, including the endogenous iron. This resulted in molar ratios (InsP/Fe) of 0.4 for the TM meal and 1.7 for the BBM meal. Water was added up to a total volume of $300 \mathrm{ml}$ before introducing the meal into the gastric compartment.

\section{Chemicals}

For the human study, isotopes ${ }^{59} \mathrm{Fe}$ and ${ }^{55} \mathrm{Fe}$ were purchased from Perkin Elmer Life Science (USA). The isotope solutions ${ }^{55} \mathrm{Fe}$ and ${ }^{59} \mathrm{Fe}$ were prepared in $0.1 \mathrm{~mol} / 1 \mathrm{HCl}$ and $55.5 \mathrm{kBq}$ was given of ${ }^{59} \mathrm{Fe}$ and $148 \mathrm{kBq}$ of ${ }^{55} \mathrm{Fe} .{ }^{59} \mathrm{Fe}$ was checked for activity in a whole body counter at the Radiation Physics Department (Göteborg) before use. In the in vitro experiments, porcine bile extracts (B-8631), porcine stomach mucosal pepsin A (2260 units/mg, P-7012), bovine pancreatic trypsin $(7500 \mathrm{~N}$ - $\alpha$-benzoyl-L-arginine ethyl ester (BAEE) units/mg T-4665), porcine pancreatin (4*U.S.P., P1750) (Sigma-Aldrich, Stockholm, Sweden) and lipase (150,000 units/mg, F-AP 15) (Amano Enzyme Inc. Nagoya, Japan) were used.

\section{Analytical Methods \\ Preparatory Analyses}

Tempe and reference material were analysed for inositol phosphates $\left(\mathrm{InsP}_{3-6}\right)$ and iron content. Samples were freeze dried (Hetosicc, Heto Birkerød, Denmark) and finely ground in a coffee grinder (Krups 75, type 203E). Determination of dry matter was performed on a moisture balance (Precisa $\mathrm{Ha}$ 300, Zürich, Switzerland). InsP analyses were performed according to Carlsson et al. [43] (method CV $= \pm 2.7 \%$, for barley samples) by extraction with $\mathrm{HCl}(0.5 \mathrm{M})$ and quantification with High Performance Ion Exchange Liquid Chromatography (HPIC). Iron content was determined in samples completely dissolved by heating in $\mathrm{HCl}$ and $\mathrm{HNO}_{3}$ and deionised water in a high-pressure microwave oven (Ethos Plus, Milestone Microwave Laboratory Systems). Iron analysis was performed by HPIC according to Fredrikson et al. [44] (method $\mathrm{CV}= \pm 1.2 \%$ for Fe contents $>1 \mathrm{ppm}$ ).

\section{Human Iron Absorption}

The analysis of ${ }^{55} \mathrm{Fe}$ and ${ }^{59} \mathrm{Fe}$ concentrations in blood was undertaken with minor modifications of the method by Eakins and Brown [45], using a liquid-scintillation spectrometer (Tri-Carb, Packard Instruments, San Antonio). Relative absorption of the isotopes ${ }^{55} \mathrm{Fe}$ and ${ }^{59} \mathrm{Fe}$ was determined in the blood, while the absolute absorption of ${ }^{59} \mathrm{Fe}$ was measured by whole-body counting. The absolute absorption of ${ }^{55} \mathrm{Fe}$ was calculated from the absolute absorption of ${ }^{59} \mathrm{Fe}$ and the relative absorption of ${ }^{55} \mathrm{Fe}$ and ${ }^{59} \mathrm{Fe}$ in the blood. Procedures and methods have previously been described by BjörnRassmussen et al. [46]. The results were statistically evaluated by t-Test: Paired Two Sample for Means.

\section{In Vitro Iron Availability}

The samples from the collected dialysates were analysed for iron content with minor modifications by HPIC using the 
Table 3. Iron Absorption from a TM and a BBM Meal ( 115 g, w.w.) of the Human Study

\begin{tabular}{|c|c|c|c|c|}
\hline & \multicolumn{2}{|c|}{ TM } & \multicolumn{2}{c|}{ BBM } \\
\hline Subjects & ${ }^{\mathrm{a}} \boldsymbol{\mu g}$ & ${ }^{\mathrm{b}} \%$ & ${ }^{\mathrm{a}} \boldsymbol{\mu g}$ & ${ }^{\mathrm{b}} \%$ \\
\hline \hline $\mathrm{F}^{\mathrm{BD}}$ & 111 & 3.70 & 93 & 3.10 \\
\hline $\mathrm{F}$ & 48 & 1.60 & 45 & 1.50 \\
\hline $\mathrm{F}$ & 102 & 3.40 & 39 & 1.30 \\
\hline $\mathrm{F}^{\mathrm{BD}}$ & 156 & 5.20 & 132 & 4.40 \\
\hline $\mathrm{M}^{\mathrm{BD}}$ & 399 & 13.30 & 171 & 5.70 \\
\hline $\mathrm{F}^{\mathrm{BD}}$ & 66 & 2.20 & 18 & 0.60 \\
\hline $\mathrm{F}$ & 93 & 3.10 & 69 & 2.30 \\
\hline $\mathrm{M}^{\mathrm{BD}}$ & 336 & 11.20 & 156 & 5.20 \\
\hline $\mathrm{Mean}$ & $164 *$ & $5.5 *$ & 90 & 3.0 \\
\hline $\mathrm{SEM}^{*}$ & 46 & 1.5 & 20 & 0.7 \\
\hline
\end{tabular}

$\mathrm{F}=$ Female, $\mathrm{M}=$ Male, ${ }^{\mathrm{BD}}$ Blood donor, ${ }^{\mathrm{a}}$ The amount of iron absorbed from the meals, ${ }^{\mathrm{b}}$ Iron absorption expressed as a fraction of total iron, *The value is significantly different from the value of the reference meal $(\mathrm{p}<0.05)$.

method by Fredrikson et al. [44]. To $0.8 \mathrm{ml}$ of the dialysate sample, $0.1 \mathrm{ml}$ of ascorbic acid $(20 \mathrm{mg} / \mathrm{ml})$ was added and samples were spiked with $0.1 \mu \mathrm{g} F / \mathrm{ml}$ sample $(0.1 \mathrm{ml}, 1$ $\mu \mathrm{g} / \mathrm{ml})$. The results were statistically evaluated using t-Test: Paired Two Sample for Means.

\section{RESULTS}

The human iron absorption and the in vitro available iron from tempe fermented barley meals (TM) and boiled barley meals (BBM) are presented in Tables 3 and 4 . In the human study, the iron absorption was significantly $(\mathrm{p}<0.05)$ increased by $94 \pm 3 \%$ from $3.0 \pm 0.7 \%$ in BBM to $5.5 \pm 1.5 \%$ in TM. The combination of high serum-ferritin and high serumFe values in a subject, resulted in low absorption values, and vice versa. In vitro available iron was significantly $(p<0.001)$ increased from $1.7 \pm 0.1 \%$ in BBM to $4.9 \pm 0.2 \%$ in TM.

Table 4. Iron Available from a TM and a BBM Meal ( $\sim 57 \mathrm{~g}$, w.w.) of the in vitro Study

\begin{tabular}{|c|c|c|c|c|}
\hline & \multicolumn{2}{|c|}{ TM } & \multicolumn{2}{c|}{ BBM } \\
\hline & ${ }^{a} \boldsymbol{\mu} \mathbf{g}$ & ${ }^{\mathrm{b}} \boldsymbol{\%}$ & ${ }^{\mathrm{a}} \boldsymbol{\mu g}$ & ${ }^{\mathrm{b}} \boldsymbol{\%}$ \\
\hline \hline I & 368.2 & 4.7 & 95.5 & 1.3 \\
\hline II & 371.4 & 4.8 & 138.1 & 1.8 \\
\hline III & 348.1 & 4.5 & 140.0 & 1.9 \\
\hline IV & 428.7 & 5.5 & 124.6 & 1.7 \\
\hline Mean & $379^{*}$ & $4.9^{*}$ & 125 & 1.7 \\
\hline SEM & 17 & 0.2 & 10 & 0.1 \\
\hline${ }^{\mathrm{c}} \mathrm{CV}(\%)$ & 9.1 & & 16.5 & \\
\hline
\end{tabular}

${ }^{\mathrm{a}}$ The amount of iron available after simulated digestion, ${ }^{\mathrm{b}}$ Iron availability expressed as a fraction of total iron, ${ }^{c}$ coefficient of variation, $*$ The value is significantly different from the value of the reference meal $(\mathrm{p}<0.001)$.

\section{DISCUSSION}

The influence of phytate content reduction in whole grain barley on iron absorption and iron availability was investigated. In both human and in vitro studies, the phytate-P content of the TM was below $10 \mathrm{mg}(6.5 \mathrm{mg} / 3.3 \mathrm{mg})$, and in the BBM above $10 \mathrm{mg}(72.3 \mathrm{mg} / 36.2 \mathrm{mg})$. The InsP/Fe molar ratio of the TM was below 1 in both the human and the in vitro studies (ratios 0.8 and 0.4 ), while the InsP/Fe ratios of the BBM of the human and in vitro studies were above 1 (ratios 8.4 and 1.7). In the study by Brune et al. [28], $\mathrm{InsP}_{6}$ was found to inhibit iron absorption, and $\mathrm{InsP}_{5}-\mathrm{InsP}_{3}$ were also suggested to influence absorption, which was later confirmed by Sandberg et al. [47]. In the present study, the $\mathrm{InsP}_{3-6}$ content of the TM was reduced to $0.36 \mu \mathrm{mol} / \mathrm{g}$ (w.w.) by an optimised tempe fermentation process [30], therefore an increase in absorption and availability of iron was expected.

Human absorption of iron was increased by $94 \pm 0.3 \%$ from the low phytate $\left(41 \mu \mathrm{mol} \mathrm{InsP}_{3-6}\right.$ or $6.5 \mathrm{mg}$ phytate-P) barley meal compared to the high phytate $\left(452 \mu\right.$ mol $\mathrm{InsP}_{3-6}$ or $72.3 \mathrm{mg}$ phytate-P) barley meal. Despite the low phytate$\mathrm{P}$ content the iron absorption was relatively low from TM $(5.5 \pm 1.5 \%)$ as well as from BBM $(3.0 \pm 0.7 \%)$. According to the study by Brune et al. [28], phytate-P content corresponding to those of the TM and BBM meals were expected to result in $\sim 13 \%$ and $\sim 7.5 \%$ iron absorption respectively. The low iron absorption may be explained by the fact that barley kernels in both TM and BBM were largely intact, and of a high amylose/B-glucan variety [34], factors which have been suggested to induce a slow digestion and a low glycemic response [35, 48, 49]. Consequently, the release of iron from the food matrix might be restrained. This theory is supported by the study of Björn-Rasmussen et al. [50] where iron absorption was lower from a meal with polished whole rice kernels compared to a rice flour meal prepared from the polished rice. On the other hand, the isotope method assumes labelling iron to be fully exchanged in food during preparations, which might not be the case with intact kernels [51]. In the study on unpolished rice by Björn-Rasmussen et al. [50], the mean iron absorption of an extrinsic tracer was significantly higher $(4.60 \pm 1.90 \%)$ than of an intrinsic tracer $(2.72 \pm 1.07 \%)$ from the same meal, suggesting that structures such as the aleurone layer impair the rate of diffusion of extrinsic tracers into the kernels, which then would result in a false to high absorption of the extrinsic tracer. However, our study shows similar results to the study by Larsson et al. [52] where the iron absorption from malted, milled oat porridge with low phytate content $\left(231 \mu \mathrm{mol} \mathrm{InsP_{3-6 }}\right.$ or $37.0 \mathrm{mg}$ phytate-P) was increased to $6.0 \%$ from $4.4 \%$ compared to a high phytate $\left(452 \mu \mathrm{mol} \mathrm{InsP}_{3-6}\right.$ or $83.7 \mathrm{mg}$ phytate-P) milled oat porridge meal.

To accurately predict iron absorption using in vitro methods presents a challenge, since a number of the factors involved in human iron absorption are difficult to mimic [33]. Nevertheless, attempts can be made to simulate the different stages of bioavailability in vitro [33]. Dialyzability is designed to predict the first step - availability. Using the TIM model, the digestion processes are simulated, allowing for measurements of the dialyzability. The in vitro and the human study were both performed on identically prepared test meals, however, the in vitro meals were halved and the 
amount of added iron was increased due to the nature of the model. The in vitro obtained data were validated against the human absorption data.

The in vitro availability was found to increase nearly three times from $1.7 \pm 0.1 \%$ of total iron available in BBM

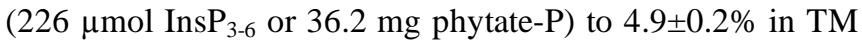
(20 $\mu \mathrm{mol} \mathrm{Ins} \mathrm{P}_{3-6}$ or $3.3 \mathrm{mg}$ phytate-P). The in vitro results for the TM correspond well to the human study, but the results from the BBM shows a larger discrepancy. Since iron becomes chelated by phytate and a large dilution of sample fluids occurs during the in vitro experiment, dialyzable iron concentration can become very low in a high-phytate meal and may therefore be underestimated. Nevertheless, the direction of the results are consistent with the results from the human study, i.e. iron availability is increased from TM as compared to the reference meal. The gastrointestinal model has also previously been used to evaluate iron availability from low phytate meals. The results of the present study concur with those of Haraldsson et al. [41], where iron availability from barley porridge was increased from $0.4 \%$ in unprocessed high phytate barley $\left(511 \mu \mathrm{mol} \mathrm{Ins} \mathrm{P}_{3-6}\right.$ or $85.7 \mathrm{mg}$ phytate-P) up to $7.9 \%$ in low phytate malted barley $(13 \mu \mathrm{mol}$ $\mathrm{InsP}_{3-6}$ or $2.2 \mathrm{mg}$ phytate-P). Furthermore, in vitro results on dephytinized pea and soy protein meals, described by Sandberg [53], also compare well with the human study by Davidsson et al. [54] using identical meals.

This is a model study on the effect of phytate removal on the iron availability and absorption. Very simple meals were chosen in order not to have any interfering effects from other food items. Iron was added to increase the accuracy in measuring the inhibitory effect of phytate, and to have equal content of iron in the test meals. The added iron could be considered as coming from a second food item in a composite meal.

Hence, this investigation demonstrates that fractional iron absorption can be improved by phytate content reduction via tempe fermentation of whole grain barley. Barley tempe could therefore contribute to novel vegetarian products with high nutritional value and high iron bioavailability. The experiments also show that it is technically feasible to reproducibly determine relative availability of iron from cereal products with the in vitro model, and that it is a potential tool for prediction of in vivo bioavailability.

\section{ACKNOWLEDGEMENTS}

We would like to acknowledge Rickard Jonsson and Therese Christerson at Svalöf Weibull AB for providing the cultivars and sharing important knowledge, and Ingmar Börjesson, Per Berthelson and Lena Rimsten at Cerealia R\&D for producing the tempe and contributing their expertise. The investigation was financed by VINNOVA Swedish Agency for Innovation Systems (Dnr 2004-02301).

\section{REFERENCES}

[1] Hunt JR, Roughead ZK. Nonheme-iron absorption, fecal ferritin excretion, and blood indexes of iron status in women consuming controlled lactoovovegetarian diets for $8 \mathrm{wk}$. Am J Clin Nutr 1999; 69(5): 944-52.

[2] Hurrell RF. Influence of vegetable protein sources on trace element and mineral bioavailability. J Nutr 2003; 133(9): 2973S-7S.

[3] Wilson AK, Ball MJ. Nutrient intake and iron status of Australian male vegetarians. Eur J Clin Nutr 1999; 53(3): 189-94.
[4] Waldmann A, Koschizke JW, Leitzmann C, Hahn A. Dietary iron intake and iron status of German female vegans: results of the German vegan study. Ann Nutr Metab 2004; 48(2): 103-8.

[5] Alexander D, Ball MJ, Mann J. Nutrient intake and haematological status of vegetarians and age-sex matched omnivores. Eur J Clin Nutr 1994; 48(8): 538-46.

[6] Anderson JW. Whole grains and coronary heart disease: the whole kernel of truth. Am J Clin Nutr 2004; 80(6): 1459-60.

[7] Kris-Etherton PM, Hecker KD, Bonanome A, et al. Bioactive compounds in foods: their role in the prevention of cardiovascular disease and cancer. Am J Med 2002; 113(9 Suppl 2): 71-88.

[8] Liu S, Stampfer MJ, Hu FB, et al. Whole-grain consumption and risk of coronary heart disease: results from the Nurses' Health Study. Am J Clin Nutr 1999; 70(3): 412-9.

[9] Montonen J, Knekt P, Jarvinen R, Aromaa A, Reunanen A. Wholegrain and fiber intake and the incidence of type 2 diabetes. Am $\mathrm{J}$ Clin Nutr 2003; 77(3): 622-9.

[10] Jordbrukverket. Swedish Board of Agriculture; Usage of barley Extract from The Eurostat report 2005-2006.

[11] Duffus CM, Cochrane MP. Formation of the barley grain - morphology, physiology, and biochemistry. In: MacGregor AW, Bhatty RS, editors. Barley: Chemistry and Technology. Edinburgh, Scotland, UK: American association of cereal chemists, Inc. St. Paul, Minnesota, USA; 1993; pp. 31-67.

[12] Lolas GM, Markakis P. Phytic acid and other phosphorous compounds of beans. J Agric Food Chem 1975; 23(1): 13-5.

[13] Quinde-Axtell Z, Baik BK. Phenolic compounds of barley grain and their implication in food product discoloration. J Agric Food Chem 2006; 54(26): 9978-84.

[14] Rocha-Guzmán NE, González-Laredo RF, Ibarra-Pérez FJ, NavaBerumen CA, Gallegos-Infante JA. Effect of pressure cooking on the antioxidant activity of extracts from three common bean (Phaseolus vulgaris L.) cultivars. Food Chem 2007; 100(1): 31-5.

[15] Towo E, Matuschek E, Svanberg U. Fermentation and enzyme treatment of tannin sorghum gruels: effects on phenolic compounds, phytate and in vitro accessible iron. Food Chem 2006; 94(3): 369-76

[16] Maillard MN, Soum MH, Boivin P, Berset C. Antioxidant Activity of Barley and Malt: Relationship with Phenolic Content. LWT 1996; 29(3): 238-44

[17] Steiner T, Mosenthin R, Zimmermann B, Greiner R, Roth S. Distribution of phytase activity, total phosphorus and phytate phosphorus in legume seeds, cereals and cereal by-products as influenced by harvest year and cultivar. Anim Feed Sci Technol 2007; 133(34): 320-34.

[18] Sandberg A-S, Rossander-Hulthén L, Türk M. Dietary Aspergillus niger phytase increases iron absorption in humans. J Nutr 1996 126(2): 476-80.

[19] Sandberg A-S, Svanberg U. Phytate hydrolysis by phytase in cereals: effects on in vitro estimation of iron availability. J Food Sci 1991; 56(5): 1330-3.

[20] Konietzny U, Greiner R. Molecular and catalytic properties of phytate-degrading enzymes (phytases). Int J Food Sci Technol 2002; 37(7): 791-812.

[21] Greiner R, Jany KD, Larsson Alminger M. Identification and Properties of myo -Inositol Hexakisphosphate Phosphohydrolases (Phytases) from Barley (Hordeum vulgare). J Cer Sci 2000; 31(2): 127.

[22] Sutardi, Buckle KA. Characterization of extra- and intracellular phytases from Rhizopus oligosporus used in tempeh production. Int J Food Microbiol 1988; 6(1): 67-79.

[23] Casey A, Walsh G. Identification and characterization of a phytase of potential commercial interest. J Biotechnol 2004; 110: 313-22.

[24] Ramachandran S, Roopesh K, Nampoothiri KM, Szakacs G, Pandey A. Mixed substrate fermentation for the production of phytase by Rhizopus spp. using oilcakes as substrates. Proc Biochem 2005; 40(5): 1749-54.

[25] Sutardi, Buckle KA. Phytic acid changes in soybeans fermented by traditional inoculum and six strains of Rhizopus oligosporus. J Appl Bact 1984; 58: 539-43.

[26] Sutardi, Buckle KA. Reduction in phytic acid levels in soybeans during tempeh production, storage and frying. J Food Sci 1985; 50: 260-3.

[27] Hallberg L, Brune M, Rossander L. Iron absorption in man: Ascorbic acid and dose-dependent inhibition by phytate. Am J Clin Nutr 1989; 49(1): 140-4. 
[28] Brune M, Rossander-Hultén L, Hallberg L, Gleerup A, Sandberg A-S. Iron absorption from bread in humans: Inhibiting effects of cereal fiber, phytate and inositol phosphates with different numbers of phosphate groups. J Nutr 1992; 122(3): 442-9.

[29] Hurrell RF. Phytic acid degradation as a means of improving iron absorption. Int J Vit Nutr Res 2004; 74(6): 445-52.

[30] Eklund-Jonsson C, Sandberg A-S, Larsson Alminger M. Reduction of phytate content while preserving minerals during whole grain cereal tempe fermentation. J Cer Sci 2006; 44(2): 154-60.

[31] Reddy MB, Cook JD. Assessment of dietary determinants of nonheme-iron absorption in humans and rats. Am J Clin Nutr 1991; 54(4): 723-8.

[32] Fairweather-Tait SJ. Iron nutrition in the UK: getting the balance right. Proc Nutr Soc 2004; 63(4): 519-28.

[33] Fairweather-Tait S, Lynch S, Hotz C, et al. The usefulness of in vitro models to predict the bioavailability of iron and zinc: a consensus statement from the HarvestPlus expert consultation. Int J Vit Nutr Res 2005; 75(6): 371-4.

[34] Ajithkumar A, Andersson R, Christerson T, Åman P. Amylose and ß-Glucan Content of New Waxy Barleys. Starch 2005; 57(6): 2359.

[35] Alminger M, Eklund-Jonsson C. Whole-grain cereal products based on a high fibre barley or oat genotype lower post-prandial glucose and insulin responses in healthy humans. 2008 (Submitted).

[36] Feng XM, Eriksson ARB, Schnurer J. Growth of lactic acid bacteria and Rhizopus oligosporus during barley tempeh fermentation. Int J Food Microbiol 2005; 104(3): 249-56.

[37] Hallberg L. Food iron absorption. In: Cook JD, editor. Methods in Haemathology. London; 1980.

[38] Minekus M, Marteau P, Havenaar R, Huis in't Veld JHJ. A multicompartimental dynamic computer-controlled model simulating the stomach and small intestine. ATLA 1995; 23: 197-209.

[39] Larsson M, Minekus M, Havenaar R. Estimation of the bioavailability of iron and phosphorus in cereals using a dynamic in vitro gastrointestinal model. J Sci Food Agric 1997; 74(1): 99-106.

[40] Salovaara S, Larsson Alminger M, Eklund-Jonsson C, Andlid T, Sandberg A-S. Prolonged transit time through the stomach and small intestine improves iron dialyzability and uptake in vitro. $\mathrm{J}$ Agric Food Chem 2003; 51(17): 5131-6.

[41] Haraldsson A-K, Rimsten L, Alminger M, Andersson R, Aman P, Sandberg A-S. Digestion of barley malt porridges in a gastrointestinal model: Iron dialysability, iron uptake by Caco- 2 cells and degradation of [beta]-glucan. J Cer Sci 2005; 42: 243-54.

[42] Blanquet S, Antonelli R, Laforet L, Denis S, Marol-Bonnin S, Alric M. Living recombinant Saccharomyces cerevisiae secreting pro- teins or peptides as a new drug delivery system in the gut. J Biotechnol 2004; 110(1): 37-49.

[43] Carlsson N-G, Bergman E-L, Skoglund E, Hasselblad K, Sandberg A-S. Rapid analysis of inositol phosphates. J Agric Food Chem 2001; 49(4): 1695-701.

[44] Fredrikson M, Carlsson N-G, Almgren A, Sandberg A-S. Simultaneous and sensitive analysis of $\mathrm{Cu}, \mathrm{Ni}, \mathrm{Zn}, \mathrm{Co}, \mathrm{Mn}$, and $\mathrm{Fe}$ in food and biological samples by ion chromatography. J Agric Food Chem 2002; 50(1): 59-65.

[45] Eakins J, Brown DA. An improved method for the simultaneous determination of iron-55 and iron-59 in blood by liquid scintillation counting. Int J Appl Rad Isotop 1966; 17(7): 391-7.

[46] Bjorn-Rasmussen E, Hallberg L, Isaksson B, Arvidsson B. Food iron absorption in man. Applications of the two-pool extrinsic tag method to measure heme and nonheme iron absorption from the whole diet. J Clin Invest 1974; 53: 247-55.

[47] Sandberg A-S, Brune M, Carlsson N-G, Hallberg L, Skoglund E, Rossander-Hulthén L. Inositol phosphates with different numbers of phosphate groups influence iron absorption in humans. Am J Clin Nutr 1999; 70: 240-6.

[48] Stevnebo A, Sahlstrom S, Svihus B. Starch structure and degree of starch hydrolysis of small and large starch granules from barley varieties with varying amylose content. Anim Feed Sci Technol 2006; 130(1-2): 23-38.

[49] Granfeldt Y, Eliasson A-C, Björck I. An examination of the possibility of lowering the glycemic index of oats and barley flakes by minimal processing. J Nutr 2000; 130: 2207-14.

[50] Bjorn-Rasmussen E, Hallberg L, Walker RB. Food iron absorption in man. II. Isotopic exchange of iron between labeled foods and between a food and an iron salt. Am J Clin Nutr 1973; 26(12): 13119.

[51] Sayers MH, Lynch SR, Charlton RW, Bothwell TH, Walker RB, Mayet F. Iron absorption from rice meals cooked with fortified salt containing ferrous sulphate and ascorbic acid. Am J Clin Nutr 1974; 31(3): 367-75

[52] Larsson M, Rossander-Hulthen L, Sandstrom B, Sandberg AS Improved zinc and iron absorption from breakfast meals containing malted oats with reduced phytate content. Am J Clin Nutr 1996; 76(5): 677-88.

[53] Sandberg AS. Methods and options in vitro dialyzability; benefits and limitations. Int J Vit Nutr Res 2005; 75(6): 395-404.

[54] Davidsson L, Dimitriou T, Walczyk T, Hurrell RF. Iron absorption from experimental infant formulas based on pea (Pisum sativum)protein isolate: The effect of phytic acid and ascorbic acid. Br J Nutr 2001; 85(1): 59-63

(C) Eklund-Jonsson et al.; Licensee Bentham Open.

This is an open access article distributed under the terms of the Creative Commons Attribution License (http://creativecommons.org/license/by/2.5/), which permits unrestrictive use, distribution, and reproduction in any medium, provided the original work is properly cited. 